\title{
PENGETAHUAN SISWI TENTANG KEBERSIHAN ORGAN GENETALIA EKSTERNA DI SMKN 1 BANYUDONO BOYOLALI
}

\author{
Students 'Knowledge About The Cleanliness Of External Genetalians at SMKN 1 \\ Banyudono Boyolali
}

\author{
Catur Setyorini' $^{1}$, Anita Dewi Lieskusumastuti ${ }^{2}$ \\ STIKES Mamba’ul Ulum Surakarta \\ Catur.ririn@yahoo.co.id
}

\begin{abstract}
ABSTRAK
Latar Belakang: Pendidikan kesehatan reproduksi sangat penting untuk diketahui sejak dini agar dapat terhindar dari berbagai permasalahan seputar organ reproduksi. Dalam menjaga kebersihan organ reproduksi seseorang harus memiliki pengetahuan mengenai kebersihan organ reproduksi tersebut. Karena menjaga kebersihan organ reproduksi merupakan awal dari usaha menjaga kesehatan dan pada masa remaja ini pula perubahan fisik terjadi secara cepat begitu juga dengan kematangan seksual.

Tujuan penelitian: Mengetahui pengetahuan siswi di SMKN 1 Banyudono dalam menjaga kebersihan organ genetalia eksterna.

Metode: Desain penelitian adalah penelitian deskriptif dengan pendekatan survey. Subjek Penelitian adalah semua siswi kelas XII jurusan keperawatan tahun ajaran 2019/2020 di SMKN1 Banyudono Boyolali sejumlah 58 siswi. Alat pengumpulan data menggunakan kuesioner. Analisis data dengan analisis univariate menggunakan rumus distribusi frekuensi.

Hasil: Karakteristik responden semua berumur 16-20 tahun sebanyak 58 responden $(100 \%)$, mayoritas responden mendapatkan informasi tentang kebersihan organ genetalia dari guru 58 responden $(17,9 \%)$, pengetahuan siswi tentang kebersihan organ genetalia eksterna mayoritas baik sebanyak 54 responden $(93,1 \%)$ dan cukup sebanyak 4 responden $(6,9 \%)$.

Simpulan: Pengetahuan siswi tentang kebersihan organ genetalia eksterna mayoritas baik.

Kata Kunci: Pengetahuan, Kebersihan Organ Genetalia Eksterna

ABSTRACT

Background: Reproductive health education is very important to know from an early age in order to avoid various problems around the reproductive organs. In keeping the reproductive organs clean, a person must have knowledge about the cleanliness of the reproductive organs. Because maintaining the cleanliness of the reproductive organs is the beginning of efforts to maintain health and during adolescence physical changes occur rapidly as well as sexual maturity.
\end{abstract}


Research purposes: Knowing the knowledge of students at SMKN 1 Banyudono in maintaining the cleanliness of external genetalia organs.

Methods: The research design was a descriptive study with a survey approach. The research subjects were all students in class XII majoring in nursing for the 2019/2020 academic year at SMKN1 Banyudono Boyolali, totaling 58 students. The data collection tool used a questionnaire. Data analysis with univariate analysis using the frequency distribution formula.

Results: Characteristics of all respondents aged 16-20 years were 58 respondents (100\%), the majority of respondents got information about the cleanliness of the genetalia organs from the teacher, 58 respondents (17.9\%), knowledge of students about the cleanliness of external genetalia organs, the majority was good, as many as 54 respondents (93.1\%) and enough as many as 4 respondents (6.9\%).

Conclusion: The majority of students' knowledge about the cleanliness of external genetalia organs is good.

Keywords: Knowledge, Cleanliness of External Genetalia Organs

\section{PENDAHULUAN}

Masa remaja diwarnai oleh pertumbuhan, perubahan, munculnya berbagai kesempatan dan seringkali menghadapi risiko-risiko kesehatan reproduksi. Kebutuhan akan peningkatan pelayanan kesehatan dan sosial terhadap remaja semakin menjadi perhatian di seluruh penjuru dunia. Dipacu rekomendasi dari hasil International Conference Population and Development (ICPD) tahun 1994 atau yang disebut Konferensi Internasional mengnai Kependudukan dan Pembangunan, banyak organisasi diberbagai Negara telah menciptakan berbagai program agar dapat lebih memenuhi kebutuhan global, program remaja yang ada masih sangat sedikit dan terbatas serta evaluasinya masih belum memadai, namun ternyata banyak pelajaran yang dapat dipetik dari proyek perintis/percontohan dan upaya inovatif yang telah dilakukan di berbagai wilayah mengenai jenis kegiatan remaja, baik yang dapat menghasilkan perubahan yang bermakna maupun yang tidak. Banyak sekali remaja yang sudah aktif secara seksual (meski tidak selalu atas pilihan sendiri), dan diberbagai daerah atau wilayah, kira-kira separuh dari mereka sudah menikah. (Purwoastuti, 2014)

Kesehatan reproduksi adalah suatu keadaan sejahtera fisik, mental dan sosial secara utuh tidak semata-mata bebas dari penyakit atau kecacatan dalam semua hal yang berkaitan dengan sistem reproduksi, serta fungsi dan prosesnya. Pembinaan Kesehatan Reproduksi Remaja dilakukan untuk memberikan informasi dan pengetahuan yang berhubungan dengan perilaku hidup sehat bagi remaja, di samping mengatasi masalah yang ada (Suryati, 2011).

Hasil survey penduduk antar sensus 2015 menunjukkan usia 15-24 tahun mencapai 42.061 .02 juta atau sebesar 16,5\% dari total penduduk Indonesia, jumlah ini akan mengalami peningkatan hingga tahun 2030. Hasil SDKI KRR tahun 2017 menunjukkan pengetahuan remaja tentang kesehatan reproduksi di 
Indonesia masih rendah. Masalah reproduksi pada remaja perlu mendapat penanganan serius, karena masalah tersebut paling banyak muncul pada negara berkembang, seperti Indonesia karena kurang tersedianya akses untuk mendapat informasi mengenai kesehatan reproduksi. (Ayuningtyas, 2011).

Anak-anak perlu diperkenalkan sejak dini tentang fungsi dan cara merawat organ reproduksinya. Mulai dari menjaga kebersihan organ, misalnya cebok sehabis buang air kecil untuk menghindari jangan sampai terserang penyakit. Menjaga kebersihan organ reproduksi sangatlah penting, terlebih pada masa remaja. Karena menjaga kebersihan organ reproduksi merupakan awal dari usaha menjaga kesehatan dan pada masa remaja ini pula perubahan fisik terjadi secara cepat begitu juga dengan kematangan seksual. (Purwoastuti, 2014)

Dalam agama Islam pun menjelaskan bahwa betapa pentingnya menjaga kebersihan organ reproduksi, seperti sabda Rasullullah SAW "lima hal termasuk ajaran Islam, khitan, mencukur bulu kemaluan, mencabuti bulu ketiak, memangkas kumis dan memotong kuku" (HR.Imam Al-Bukhari, Hadist Shahih). Dari hadist tersebut sudahlah jelas bahwa agama Islam sangat menganjurkan untuk menjaga kebersihan organ reproduksi yaitu dengan cara khitan dan mencukur bulu kemaluan yang mana itu dapat menjauhkan seseorang dari masalah- masalah kesehatan yang timbul. (Rachma, 2016)

Organ reproduksi merupakan salah satu organ tubuh yang sensitif dan memerlukan perawatan khusus. Pada organ seksual tersebut keringat yang dihasilkan cukup berlebih. Sehingga organ seksual tersebut menjadi lebih lembab yang dapat menjadi media berkembangbiaknya bakteri, penyakit dan bau tidak sedap. (Ayuningtyas, 2011).

Pendidikan kesehatan reproduksi sangat penting untuk diketahui sejak dini agar dapat terhindar dari berbagai permasalahan seputar organ reproduksi. Dalam menjaga kebersihan organ reproduksi seseorang harus memiliki pengetahuan mengenai kebersihan organ reproduksi tersebut. Pengetahuan itu sendiri adalah hasil penginderaan manusia, atau hasil tahu seseorang terhadap objek melalui indera yang dimilikinya. Pengetahuan merupakan salah satu bagian dari perilaku, sebagaimana yang dikemukakan oleh Benyamin Bloom dalam Notoatmodjo (2012), membagi perilaku seseorang ke dalam tiga domain yakni pengetahaun (cognitive domain), sikap (affevtive domain), dan tindakan (psychomotor domain). Kognitif dapat diukur dari pengetahuan, afektif dari sikap atau tanggapan dan psikomotor diukur melalui tindakan (praktik) yang dilakukan (Notoatmodjo, 2012).

Pengetahuan atau kognitif merupakan domain yang sangat penting untuk terbentuknya tindakan seseorang (overt behavior). Pemahaman seseorang terhadap kesehatan reproduksinya sangatlah penting. Seseorang yang tidak memiliki pengetahuan tentang kesehatan reproduksi yang cukup, akan cenderung mengabaikan kesehatan reproduksinya dan pada akhirnya ia akan melakukan tindakan yang membahayakan bagi dirinya sendiri. Rendahnya pengetahuan tentang kesehatan reproduksi akan memungkinkan seseorang tidak berperilaku 
higienis dalam menjaga organ reproduksinya yang dapat membahayakan kesehatan reproduksinya sendiri (Notoatmodjo, 2012).

Hasil penelitian yang telah dilakukan Safira (2012) tentang gambaran tingkat pengetahuan perempuan dan angka keluhan keputihan pada remaja putri di SMAN 1 Bogor yang menemukan 57\% dari 81 responden memiliki keluhan keputihan, selain itu penelitian yang telah dilakukan oleh Amelia dan Yetty (2014) menunjukkan hasil 44,1\% siswi mempunyai perilaku baik dan 55,9\% siswi memiliki perilaku buruk dalam menjaga kebersihan area genetalia. Serta penelitian yang telah dilakukan oleh Delvia (2016) menunjukkan adanya hubungan yang bermakna antara personal hygiene dengan keluhan pada genetalia eksternal, Salah satu dampak yang bisa terjadi bila tidak menjaga kebersihan tubuh diantaranya muncul bau khas dari daerah vagina, karena dinding vagina serta leher rahim mengeluarkan cairan.

Dari hasil studi pendahuluan yang dilakukan di SMKN 1 Banyudono, didapatkan bahwa masih terdapat siswi yang sering mengalami keputihan dan menggunakan sabun pembersih vagina untuk membersihkan alat genetalianya. Berdasarkan uraian diatas, penulis tertarik untuk melakukan penelitian dengan judul "Pengetahuan siswi tentang kebersihan organ genetalia eksterna"

\section{METODE}

Desain penelitian adalah penelitian deskriptif dengan pendekatan cross sectional. Variabel dalam penelitian ini adalah Pengetahuan siswi tentang kebersihan organ genetalia eksterna. Penelitian ini menggunakan total sampling, sehingga subjek penelitian adalah semua siswi kelas XII jurusan keperawatan tahun ajaran 2019/2020 di SMKN1 Banyudono Boyolali sejumlah 58 siswi. Alat pengumpulan data menggunakan kuesioner yang telah dilakukan uji validitas dan reliabilitas dalam Penelitian Rachma (2016) yang terdiri atas 16 pernyataan.

Metode pengumpulan data dengan data primer dan sekunder. Data primer dengan membagikan kuesioner pada siswi kelas XII jurusan Keperawatan SMKN1 Banyudono tahun ajaran 2019/2020, sedangkan data sekunder diambil dari data jumlah siswi kelas XII jurusan Keperawatan di bagian kesiswaan SMKN 1 Banyudono Boyolali. Analisis Data menggunakan rumus distribusi frekuensi.

\section{HASIL DAN PEMBAHASAN}

\section{Hasil}

1. Karakteristik responden berdasarkan umur.

Tabel 1 Distribusi frekuensi karakteristik responden berdasarkan umur

\begin{tabular}{cccc}
\hline No & Umur & Frekuensi & Prosentase(\%) \\
\hline 1 & $10-15$ tahun & 0 & 0 \\
2 & $16-20$ tahun & 58 & 100 \\
& Jumlah & 58 & 100 \\
\hline
\end{tabular}

Sumber: Data primer 2020 
Berdasarkan tabel 1 di atas dapat disimpulkan responden berumur 16-20 tahun sebanyak 58 responden $(100 \%)$.

2. Karakteristik responden berdasarkan sumber informasi

Tabel 2 Distribusi frekuensi karakteristik responden berdasarkan sumber informasi

\begin{tabular}{clcc}
\hline No & \multicolumn{1}{c}{ Pendidikan } & Frekuensi & Prosentase $(\%)$ \\
\hline 1 & Tenaga Kesehatan & 40 & 12,5 \\
2 & Orang Tua & 44 & 13,6 \\
3 & Teman & 33 & 10,2 \\
4 & Guru & 58 & 17,9 \\
5 & Buku Pelajaran & 41 & 12,7 \\
6 & Internet & 45 & 13,9 \\
7 & Majalah/ surat kabar & 31 & 9,6 \\
8 & TV/ radio & 31 & 9,6 \\
& Jumlah & 323 & 100 \\
\hline
\end{tabular}

Sumber: Data primer 2020

Berdasarkan tabel 2 di atas dapat disimpulkan sebagian besar responden mendapatkan informasi dari guru sebanyak $17,9 \%$.

\section{Pengetahun Siswi tentang Kebersihan Organ Genetalia Eksterna}

Tabel 4.4 Distribusi frekuensi Pengetahun Siswi tentang Kebersihan Organ Genetalia Eksterna

Sumber: Data primer 2020

\begin{tabular}{clcc}
\hline No & \multicolumn{1}{c}{ Sikap } & Frekuensi & Prosentase(\%) \\
\hline 1 & Baik & 54 & 93,1 \\
2 & Cukup & 4 & 6,9 \\
3 & Kurang & 0 & 0 \\
& Jumlah & 58 & 100 \\
\hline
\end{tabular}

Berdasarkan tabel 3 di atas dapat disimpulkan sebagian besar responden memiliki pengetahuan yang baik sebanyak 54 responden $(93,1 \%)$.

\section{Pembahasan}

Siswi SMKN 1 Banyudono, Boyolali yang terlibat dalam penelitian ini sejumlah 58 siswi, dan berumur antara 16-20 tahun. Masa remaja adalah masa peralihan dari masa anak menuju masa dewasa yang disertai dengan perkembangan segala aspek yang mengarah untuk memasuki masa dewasa. Tumbuh kembang remaja dibagi menjadi tiga yaitu masa remaja awal usia 10-14 tahun, remaja menengah usia 14-17 tahun, dan remaja lanjut usia 17-20 tahun (Adriani, \& Wirjatmadi, 2016).

Masa remaja tidak terlepas dari permasalahan kesehatan, tidak terkecuali masalah kesehatan reproduksi. Kesehatan reproduksi adalah suatu keadaan sejahtera fisik, mental dan sosial secara utuh tidak semata-mata bebas dari penyakit atau kecacatan dalam semua hal yang berkaitan dengan sistem 
reproduksi, serta fungsi dan prosesnya. Pembinaan Kesehatan Reproduksi Remaja dilakukan untuk memberikan informasi dan pengetahuan yang berhubungan dengan perilaku hidup sehat bagi remaja, di samping mengatasi masalah yang ada (Suryati, 2011).

Beberapa masalah kesehatan reproduksi yang dialami remaja adalah Penyakit Menular Seksual (PMS) dan HIV, tetapi permasalahan tersebut dapat terjadi jika remaja mengalami seks pranikah (Pusat Data dan Informasi Kementerian Kesehatan RI, 2015).

Perubahan-perubahan tersebut berpengaruh terhadap sifat remaja. Sifat remaja diantaranya memiliki rasa keingintahuan yang besar, menyukai petualangan, tantangan, serta berani menanggung risiko atas perbuatannya tanpa didahului pertimbangan yang matang. Oleh karena itu, ketersediaan pelayanan kesehatan reproduksi sangat diperlukan untuk usia remaja (Pusat Data dan Informasi Kementerian Kesehatan RI, 2015).

Berdasarkan hasil tabel 2 didapatkan bahwa sumber informasi yang diperoleh responden tentang menjaga kebersihan organ genetalia eksterna semua responden menyatakan mendapat informasi dari guru sebanyak 58 responden $(17,9 \%)$, dari internet sebanyak 45 responden $(13,9 \%)$, dari orang tua sebanyak 44 responden $(13,6 \%)$, dari tenaga kesehatan sebanyak 40 responden $(12,5 \%)$, selain itu informasi juga didapat dari teman, buku pelajaran, majalah/ surat kabar dan TV/ media elektronik.

Responden dalam penelitian ini merupakan siswi SMKN1 Banyudono, Boyolali kelas XII. Ketika menduduki kelas tersebut, siswi telah mendapatkan informasi yang lebih kompleks tidak terkecuali informasi mengenai kesehatan baik melalui materi yang disampaikan guru dikelas maupun terkadang 1 tahun sekali mendapatkan penyuluhan mengenai kesehatan reproduksi dari Puskemas (Salah satu Guru SMKN 1 Banyudono, 2020). Hal ini dapat mendukung tingkat pengetahuan responden mengenai personal hygiene organ genitalia eksterna.

Pengetahuan itu sendiri adalah hasil penginderaan manusia, atau hasil tahu seseorang terhadap objek melalui indera yang dimilikinya. Pengetahuan merupakan salah satu bagian dari perilaku, sebagaimana yang dikemukakan oleh Benyamin Bloom dalam Notoatmodjo (2012), membagi perilaku seseorang ke dalam tiga domain yakni pengetahaun (cognitive domain), sikap (affevtive domain), dan tindakan (psychomotor domain). Kognitif dapat diukur dari pengetahuan, afektif dari sikap atau tanggapan dan psikomotor diukur melalui tindakan (praktik) yang dilakukan (Notoatmodjo, 2012). Seseorang yang tidak memiliki pengetahuan tentang kesehatan reproduksi yang cukup, akan cenderung mengabaikan kesehatan reproduksinya dan pada akhirnya ia akan melakukan tindakan yang membahayakan bagi dirinya sendiri. Rendahnya pengetahuan tentang kesehatan reproduksi akan memungkinkan seseorang tidak berperilaku higienis dalam menjaga organ reproduksinya yang dapat membahayakan kesehatan reproduksinya sendiri. 
Tingkat pengetahuan responden mengenai kebersihan organ genetalia eksternal tergolong baik yaitu terdapat 54 responden $(93,1 \%)$, meskipun masih terdapat 4 responden $(6,9 \%)$ yang memiliki pengetahuan yang cukup. Hal ini sejalan dengan penelitian oleh Karnita (2014) yang menunjukkan bahwa remaja putri di MTS Guppi Samata Kabupaten Gowa memiliki pengetahuan yang baik dalam menjaga personal hygiene organ reproduksi $(60,5 \%)$. Hasil penelitian ini juga sejalan dengan penelitian yang dilakukan oleh Firdaus, H dan Erni, A (2018) bahwa hasil penelitian menunjukkan tingkat pengetahuan, sikap, dan perilaku responden mengenai personal hygiene organ genitalia eksterna tergolong baik.

Organ reproduksi pada perempuan memang jauh lebih rumit dan rentan akan penyakit karena secara anatomis letak organ reproduksi perempuan berada didalam tubuh. Selain itu, letaknya yang berdekatan dengan anus dan uretra sehingga memudahkan kuman untuk masuk dan dapat menyebakan terjadinya keputihan patologis. Menjaga kebersihan organ genitalia eksterna merupakan langkah awal dalam menjaga kesehatan reproduksi (Tapparan, Fitrianti., Lampus, B. S., \& Pandelaki, dalam Firdaus, H dan Erni, A, 2018).

Beberapa cara yang dapat dilakukan untuk menjaga kebersihan organ genitalia eksterna diantaranya membersihkan alat kelamin dari arah depan ke belakang dengan menggunakan air bersih, mengeringkan organ genitalia dengan tissue atau handuk kering yang bersih, menggunakan pembalut bersih dan mengganti secara teratur 2-3 kali dalam sehari atau setiap setelah buang air kecil, atau bila pembalut telah penuh darah, atau saat mandi, serta menggunakan sabun saat membersihkan alat kelamin (Pusat Promosi Kementerian Kesehatan Republik Indonesia, 2012).

\section{SIMPULAN DAN SARAN}

\section{Simpulan}

Berdasarkan hasil penelitian yang dilakukan dapat disimpulkan sebagai berikut karakteristik responden berumur 16-20 tahun sebanyak 58 responden $(100 \%)$. Mayoritas responden mendapatkan informasi tentang kebersihan organ genetalia dari guru 58 responden (17,9\%). Pengetahuan siswi tentang kebersihan organ genetalia eksterna mayoritas baik sebanyak 54 responden $(93,1 \%)$.

\section{Saran}

Berdasarkan simpulan diatas dapat diajukan saran bahwa siswi harus lebih memperhatikan kebersihan organ genetalia eksterna dan aktif mencari informasi pada sumber yang berkompeten seperti tenaga kesehatan. Kepada guru diharapkan memberikan dorongan kepada siswi agar selalu menjaga kebersihan organ genetalia eksterna. Institusi kesehatan dapat mengadakan sosialisasi kesehatan reproduksi di sekolah-sekolah 


\section{DAFTAR PUSTAKA}

Adriani, Merryana., \& Wirjatmadi, B. 2016. Peranan Gizi dalam Siklus Kehidupan. Jakarta: Prenadamedia Group.

Amelia C, dan Yetty K. 2014. Perilaku Kebersihan Area GenetaliaPada Siswi di Sekolah Berasrama. Jurnal Fakultas Ilmu Keperawatan: Universitas Indonesia

Ayuningtyas, D. N. 2011. Hubungan Anatara Pengetahuan Dan Perilaku Manjaga Kebersihan Genetalia Eksternal Dengan Kejadian Keputihan Pada Siswi SMAN 4 Semarang. Artikel KTI. Semarang: FK UNDIP.

Delvia S. 2016. Keluhan Pada Genetalia Eksternal Ditinjau Dari Pengetahuan Dan Personal Hygiene pada siswi SMA. STIKES Aisyiah Pringsewu Lampung: Jurnal Ilmu Kesehatan Aisyiah Vol 1 No 2

Firdaus, H dan Erni, A. 2018. Gambaran Pengetahuan Sikap Dan Perilaku Personal Hygiene Organ Genitalia Eksterna Siswi Smp Di Kabupaten Banyuwangi. Journal Unair Vol 2 No 1.

Karnita, R. 2014. Gambaran Pengetahuan dan Sikap Remaja Putri Tentang Personal hygiene Organ Reproduksi di Mts. Guppi Samata Kabupaten Gowa, (Karya Tulis Ilmiah, Universitas Islam Negeri Alaudin, Makassar). Diakses dari: http://repositori.uinalauddin.ac.id/4931/1/riza karnita_opt.pdf.

Kusmiran, Eny. 2012. Kesehatan Reproduksi Remaja dan Wanita. Jakarta: Salemba Medika.

Notoatmodjo, Soekidjo. 2012. Metodologi Penelitian Kesehatan. Jakarta: Rineka Cipta

Nurlita W. 2014. Gambaran Tingkat Pengetahuan Dan Perilaku Menjaga Kebersihan Organ Genetalia Eksterna Pada Siswi MI Pembangunan. Skripsi. Program Studi Ilmu Keperawatan Fakultas Kedokteran Dan Ilmu KesehatanUniversitas Islam Negeri Syarif Hidayatullah Jakarta

Peraturan Pemerintah Republik Indonesia No 61 tahun 2014 tentang Kesehatan Reproduksi

Purwoastuti, E. 2014. Panduan Materi Kesehatan Reproduksi dan Keluarga Berencana. Yogyakarta: Pustaka Baru.

Pusat Data dan Informasi Kementerian Kesehatan RI. 2015. Situasi Kesehatan Reproduksi Remaja. Diakses dari: http://www.depkes.go.id/resources/download/pusdatin/infodatin/infodatin\% 2520reproduksi\%2520remaja-ed.pdf

Pusat Promosi Kementerian Kesehatan Republik Indonesia. 2012. Buku Petunjuk Penggunaan Media KIE Versi Pekerja dan Mahasiswa. Diakses dari: http://www.depkes.go.id/resources/download/promosikesehatan/juknis-media-kieabat-mahasiswa-dan-pekerja.pdf

Rachma AA. 2016. Gambaran Tingkat Pengetahuan Remaja Tentang Kebersihan Organ Genetalia Eksterna Di SMAN 90 Jakarta. Skripsi. Jakarta: UIN Syarif Hidayatullah 
Safira. 2012. Gambaran Tingkat Pengetahuan tentang perawatan organ reproduksi wanita dan angka keluhan keputihan pada remaja putri di SMAN I Bogor. Depok:Universitas Indonesia.

Suryati Romauli, S. ST., An Vida Vindari, S.ST, 2011, Kesehatan Reproduksi. Yogyakarta: Nuha Medika. 